\title{
Implementasi Peraturan Walikota Binjai Nomor 47 Tahun 2017 tentang Sistem dan Prosedur Pemungutan Pajak Bumi dan Bangunan Perdesaan dan Perkotaan dan Kaitannya dengan Intensifikasi Penerimaan di Kota Binjai
}

\section{Implementation of Mayor of Binjai Regulation Number 47 of 2017 Concerning the System and Procedure of Collecting Rural and Urban Land and Building Taxes and their Relation to Intensification Revenue in Binjai City Ahmad Fauzan Nasution'), Siti Mardiana ${ }^{2)}$ dan Isnaini ${ }^{3)}$}

1) Magister Program Studi Administrasi Publik, Universitas Medan Area, Indonesia

2) Fakultas Pertanian, Universitas Medan Area, Indonesia

3) Fakultas Hukum, Universitas Medan Area, Indonesia

\section{Abstrak}

Diberlakukannya Undang-Undang Nomor 28 Tahun 2009 tentang Pajak Daerah dan Retribusi Daerah, berarti seluruh kewenangan dalam hal pengelolaan Pajak Daerah sepenuhnya dialihkan kepada Pemerintah Daerah. Sejak diserahkannya pengelolaan Pajak Bumi dan Bangunan Perdesaan dan Perkotaan (PBB P2) dari Pemerintah Pusat ke Pemerintah Daerah, Pemerintah Kota Binjai melalui Badan Pengelolaan Keuangan Pendapatan dan Aset Daerah Kota Binjai telah melakukan berbagai upaya intensifikasi agar penerimaan pajak daerah khususnya PBB P2 dapat berjalan optimal yaitu dengan menerbitkan Peraturan Walikota Binjai Nomor 47 Tahun 2017 tentang Sistem dan Prosedur Pemungutan PBB P2.Penelitian ini bertujuan untuk menganalisisImplementasi Peraturan Walikota Binjai Nomor 47 Tahun 2017 dengan melihat program kebijakan yang dilaksanakan, hambatan-hambatan yang dihadapi, serta usaha-usaha yang dilakukan terkait dengan intensifikasi guna meningkatkan penerimaan PBB P2 di Kota Binjai.Penelitian ini merupakan penelitian deskriptif dengan pendekatan kualitatif yaitu prosedur pemecahan masalah yang diselidiki dengan menggambarkan keadaan subjek/objek penelitian pada saat sekarang berdasarkan fakta yang tampak.

Kata Kunci: Implementasi, Intensifikasi, Pajak Bumi dan Bangunan

\section{Abstract}

The enactment of Law Number 28 of 2009 concerning Regional Taxes and Regional Retributions, means that all authorities in terms of management of Regional Taxes are fully transferred to Regional Governments. Since the management of the Rural and Urban Land and Building Tax (PBB P2) from the Central Government to the Regional Government, the Binjai City Government through the Regional Income and Asset Financial Management Agency of the City of Binjai has carried out various intensification efforts so that regional tax revenues, especially Land and Building Taxes can run optimal, namely by issuing Mayor Binjai Regulation Number 47 of 2017 concerning PBB Collection System and Procedure P2. This study aims to analyze the Implementation of Mayor Binjai Regulation Number 47 of 2017 by looking at the policy programs implemented, the obstacles faced, and the efforts made related to intensification in order to increase the acceptance of PBB P2 in Binjai City. This research is a descriptive study with a qualitative approach, namely the problem solving procedure that is investigated by describing the state of the subject / object of research at present based on visible facts.

Keywords: Implementation, Intensification, Land and Building Tax

How to Cite: Fauzan A, Mardiana S \& Isnaini (2020). Implementasi Peraturan Walikota Binjai Nomor 47 Tahun 2017 tentang Sistem dan Prosedur Pemungutan Pajak Bumi dan Bangunan Perdesaan dan Perkotaan dan Kaitannya dengan Intensifikasi Penerimaan di Kota Binjai. Strukturasi: Jurnal Ilmiah Magister Administrasi Publik, 1(1) 2020: 52-64,

*E-mail: abdullahafifudin@gmail.com

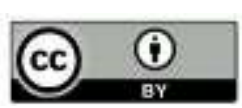




\section{PENDAHULUAN}

Dengan adanya Undang-Undang otonomi daerah memacu seluruh pemerintah daerah di Indonesia berlomba-lomba untuk menggali potensi yang terdapat di daerahnya masing-masing guna menciptakan pemerintahan daerah yang mandiri dan menciptakan masyarakat yang sejahtera. Berbagai usaha yang diakomodir dalam Undang-Undang dan peraturan yang berlaku diselenggarakan dalam rangka usaha meningkatkan Pendapatan Asli Daerah (PAD) (Ngarsiningtyas \& Sembiring, 2016). Pendapatan Asli Daerah merupakan semua penerimaan daerah yang berasal dari sumber ekonomi asli daerah. Dengan ditambahnya infrastruktur dan perbaikan infrastruktur yang ada oleh pemerintah daerah, diharapkan akan memacu pertumbuhan perekonomian di daerah.

Untuk mewujudkan kemandirian keuangannya, setiap daerah membutuhkan dana untuk menjalankan aktivitas pemerintahan dan pembangunan, salah satunya yaitu bersumber dari sektor pajak. Pemerintah Kota Binjai melalui Badan Pengelolaan Keuangan Pendapatan dan Aset Daerah (BPKPAD) sebagai instansi yang mempunyai salah satu tugas pokok dan fungsi sebagai pemungut sekaligus pengelola pajak daerah telah melakukan serangkaian kegiatan untuk mengoptimalkan pendapatan yang bersumber dari pajak daerah.Diantaranya yaitu melakukan ekstensifikasi pajak dan intensifikasi pajak daerah. Peran pemungutan pajak daerah sangat dominan bagi jalannya pembangunan daerah, karena pajak yang dipungut oleh pemerintah daerah dari masyarakat digunakan untuk kesejahteraan masyarakatnya, dengan demikian maka fungsi pajak sangatlah penting.

Diberlakukannya Undang-Undang Nomor 28 Tahun 2009 tentang Pajak Daerah dan Retribusi Daerah, berarti seluruh kewenangan dalam hal pemungutan Pajak Daerah sepenuhnya dialihkan kepada Pemerintah Daerah. Berlakunya Undang-Undang tersebut menjadikan Pajak Bumi dan Bangunan Perdesaan dan Perkotaan yang selanjutnya disebut PBB-P2 dari Pajak Pusat menjadi Pajak Daerah serta diharapkan mampu menjadi salah satu sumber penerimaan Pendapatan Asli Daerah (PAD) yang potensial bagi setiap daerah. Kewenangan dalam kegiatan yang terkait dengan PBB-P2 menjadi milik Pemerintah Daerah, hal itu meliputi proses pendataan, penilaian, penetapan, pengadministrasian, pemungutan/penagihan dan pelayanan terkait PBB-P2.

PBB P2 merupakan salah satu sumber pendapatan yang potensial yang dikelola daerah. Penetapan anggaran dan realisasi PBB P2 Kota Binjai tahun 2014-2017 di Kota Binjai dapat dilihat pada tabel berikut:

\begin{tabular}{c|lll} 
Target dan Realisasi PBB P2 Kota Binjai Tahun & 2016-2018 \\
\hline Tahun & Target & Realisasi & $\%$ \\
\hline 2016 & $7.100 .000 .000,-$ & $7 \cdot 312.390 .000,-$ & 102,99 \\
2017 & $11.375 .000 .000,-$ & $8.802 .139 .503,-$ & 77,38 \\
2018 & $12.512 .500 .000,-$ & $7.706 .160 .505,-$ & 61,59 \\
\hline
\end{tabular}

Sumber: Laporan Keuangan Pemerintah Daerah (LKPD) Kota Binjai 2016-2018

Berdasarkan tabel anggaran dan realisasi penerimaan PBB P2 Kota Binjai tahun 2016-2017 dapat dilihat terjadi kenaikan dalam penetapan target/anggaran penerimaan PBB P2, namun pencapaian realisasi penerimaan PBB P2 dari tahun 2017-2018 mengalami penurunan dari target yang telah ditetapkan yaitu hanya sebesar $77,38 \%$ di tahun 2017, dan 61,59\% di tahun 2018. 
Siregar (2017) menyatakan permasalahan prinsip yang dimiliki oleh seluruh daerah otonom pada umumnya adalah terbatasnya sumber dana pendapatan yang dimiliki, khusus kota binjaipermasalahan yang dihadapi dalam upaya meningkatkan pendapatan daerah sebagai berikut:

Penentuan target Pendapatan Asli Daerah (PAD) belum mencerminkan potensi yang sebenarnya;

1. Kurangnya kesadaran Wajib Pajak/Wajib Retribusi untuk memenuhi kewajibannya;

2. Lemahnya sanksi hukum terhadap Wajib Pajak/Retribusi yang menunggak.

3. Pelayanan terhadap Wajib Pajak/Wajib Retribusi masih belum dilaksanakan secara prima;

4. Terbatasnya sumber daya manusia sebagai pelaksana operasional di lapangan;

5. Belum dimilikinya database mengenai sumber-sumber PAD;

6. Belum efektifnya sistem pengendalian dan pengawasan di lapangan.

7. Sedangkan terkhusus dalam pencapaian Pajak Bumi dan Bangunan Perdesaaan dan Perkotaan (PBB P2) di Kota Binjai, terdapat beberapa permasalahan yang dihadapi sebagai berikut:

8. Pelimpahan data pajak dan retribusi terutama data Pajak Bumi dan Bangunan dari kantor pelayanan Pajak yang relatif tidak akurat.

9. Adanya keberatan dari masyarakat selaku wajib pajak yang telah memverifikasi penetapan pajaknya sehingga timbul kendala dalam pencapaian target dari sektor pajak bumi dan bangunan.

10. Adanya ketergantungan terhadap sistem jaringan online dari pihak ketiga. Ketergantungan yang sangat tinggi kepada pihak ketiga selaku penyelenggaraan pengadaan sistem jaringan (online). Kendala yang timbul apabila dalam penyelenggaraan jaringan tersebut adanya kerusakan atau terputusnya jaringan yang sangat menghambat dalam pengaksesan data.

Pandangan aparat yang tidak menyukai perubahan sehingga cenderung untuk stagnan pada keadaan di masa lampau. Pandangan ini menghambat karena di saat peraturan baru diterapkan, kesalahan-kesalahan selalu terjadi berulang (Hendrawan, Kusmanto, \& Warjio, 2018; Sinulingga, Nasution, \& Batubara, 2018; Kadir, 2018). Aparat cenderung mencontoh kepada hal yang sudah ada, dan tidak menyukai perubahan karena perubahan berarti bertambahnya pekerjaan yang harus dilakukan.

Upaya yang dilakukan oleh BPKPAD Kota Binjai agar pemungutan PBB-P2 dapat dioptimalkan sebagai sumber PAD adalah dengan melakukan intensifikasi pemungutan PBB-P2. Intensifikasi pajak merupakan optimalisasi penggalian penerimaan pajak terhadap objek pajak serta subjek pajak yang telah tercatat atau terdaftar dalam administrasi pajak, dan dari hasil pelaksanaan ekstensifikasi Wajib Pajak. Pelaksanaan intensifikasi pajak atau penggalian potensi pajak dapat digolongkan menjadi 2, yang pertama adalah dengan cara metode langsung yang menggali potensi pajak melalui SPT dan laporan keuangan yang disampaikan oleh Wajib Pajak dan yang kedua adalah dengan cara metode tidak langsung yang menggali potensi pajak melalui pemanfaatan data di luar SPT tahunan dan laporan keuangan (Purwanto, 2013), sedangkan kegiatan ekstensifikasi pajak dilakukan dengan kegiatan yang berkaitan dengan penambahan 
jumlah Wajib Pajak terdaftar dan perluasan objek pajak dalam administrasi Direktorat Jenderal Pajak (DJP).

Pemerintah Kota Binjai telah mengeluarkan Peraturan Walikota Binjai Nomor 47 Tahun 2017 tentang Sistem dan Prosedur Pemungutan PBB P2 di Kota Binjai (Pinayungan, Kusmanto, et .all, 2018). Tujuan dikeluarkannya peraturan ini merupakan salah satu usaha dalam meningkatkan pelayanan kepada masyarakat di zaman serba digital untuk terwujudnya tertib administrasi pemungutan Pajak Bumi dan Bangunan Perdesaan dan Perkotaan (PBB-P2). Selain itu juga tujuan dari dikeluarkannya peraturan ini adalah usaha penyempurnakan sistem dan prosedur pemungutan pajak bumi dan bangunan perdesaan dan perkotaan untuk mewujudkan kepastian hukum terhadap hak dan kewajiban wajib pajak, penegakan hukum, dan meningkatkan kepatuhan wajib pajak dalam membayar PBB-P2 di Kota Binjai.

\section{METODE PENELITIAN}

Tujuan penelitian ini adalah untuk mengetahui dan menggambarkan mengenai ImplementasiPemerintah Kota Binjai telah mengeluarkan Peraturan Walikota Binjai Nomor 47 Tahun 2017 tentang Sistem dan Prosedur Pemungutan PBB P2 di Kota Binjaidengan melihat program kebijakan yang dilaksanakan, hambatan-hambatan yang dihadapi, serta usaha-usaha yang dilakukan terkait dengan intensifikasi guna meningkatkan penerimaan PBB P2 di Kota Binjai, sehingga dengan adanya hambatanhambatan tersebut peneliti dapat mengetahui upaya-upaya apa saja yang akan dilakukan dalam mengatasi hambatan tersebut.Dengan demikian penelitian ini merupakan penelitian deskriptif dengan pendekatan kualitatif yaitu prosedur pemecahan masalah yang diselidiki dengan menggambarkan keadaan subjek/objek penelitian pada saat sekarang berdasarkan fakta yang tampak.

Penelitian ini termasuk dalam jenis penelitian kualitatif. Menurut Sugiyono (2012), menjelaskan bahwa "Penelitian kualitatif merupakan penelitian yang berlandaskan pada filsafat positivisme, digunakan untuk meneliti pada kondisi obyek yang alamiah, (sebagai lawannya adalah eksperimen) dimana peneliti adalah sebagai instrumen kunci, pengambilan sampel sumber data dilakukan secara purposive dan snowball, teknik pengumpulan dengan trianggulasi, analisis data bersifat induktif/kualitatif, dan hasil penelitian kualitatif lebih menekan makna dari pada generalisasi".

Dalam menentukan informan dalam penelitian ini adalah orang-orang yang dianggap memiliki informasi kunci yang dibutuhkan di lokasi penelitian. Berdasarkan kebutuhan data yang ada, maka penulis menentukan yang menjadi para informan dalam penelitian ini adalah para pengelola PBB P2 di Kota Binjai para pengelola PBB P2 di Kota Binjai yang berada pada Badan Pengelolaan Keuangan Pendapatan dan Aset Daerah (BPKPAD) Kota Binjai. Dalam memperoleh data, peneliti menggunakan informan kunci (key informan) dan informan tambahan sebagai pelaku langsung yang terlibat dalam kegiatan pengelolaan PBB P2 di Kota Binjai.

Data primer yang digunakan dalam penelitian ini diperoleh melalui wawancara secara langsung dengan para pengelola PBB P2 di Kota Binjai yang berada pada Badan 
Pengelolaan Keuangan Pendapatan dan Aset Daerah (BPKPAD) Kota Binjai, para pejabat yang membidangi PBB P2 dan para petugas lapangan PBB P2.

Data sekunder yang digunakan diperoleh dari dokumen-dokumen laporan keuangan, peraturan-peraturan, dan sumber kepustakaan yang berhubungan dengan peraturan mengenai pengelolaan PBB P2, target dan realisasi tahunan PBB P2, serta dokumen lain yang berhubungan dengan objek yang diteliti.

Dalam menganalisis data, penulis menggunakan teknik analisa deskriptif, dimana data-data dalam bentuk kualitatif khususnya dari wawancara. Metode deskriptif adalah teknik yang dilakukan dengan mengumpulkan, mengklasifikasikan, menganalisis data yang berhubungan dengan masalah yang dihadapi, sehingga diperoleh gambaran yang jelas mengenai faktanya (Sugiyono, 2012). Metode kualitatif artinya data yang dikumpulkan bukan berupa angka-angka, melainkan data yang berasal dari kuisioner atau naskah wawancara, catatan lapangan, dokumen pribadi, catatan memo, dan dokumen resmi lainnya.

Secara induktif peneliti akan mencoba mengolah data yang bersifat kualitatif untuk menarik kesimpulan tentang bagaimana implementasi Peraturan Walikota Binjai Nomor 47 Tahun 2017 tentang Sistem dan Prosedur Pemungutan Pajak Bumi dan Perdesaan Perkotaan dan kaitannya dengan Intensifikasi PBB P2 di Kota Binjai berdasarkan teori implementasi menurut Edward III yang dipengaruhi oleh empat variabel, yakni komunikasi, sumber-sumber, kecenderungan atau tingkah laku dan struktur birokrasi (Winarno, 2008).

HASIL DAN PEMBAHASAN

Implementasi Peraturan Walikota Tentang Intensifikasi Yang Telah Dilakukan Pemerintah Kota Binjai Dalam Meningkatkan Penerimaan PBB-P2

Penelitian dilaksanakan dengan melakukan observasi atas sistem dan prosedur dan pemungutan Pajak Bumi dan Bangunan Perdesaan dan Perkotaan (PBB P2) dengan melihat program kebijakan yang dilaksanakan, hambatan-hambatan yang dihadapi, serta usaha-usaha yang dilakukan terkait dengan intensifikasi guna meningkatkan penerimaan PBB P2 di Kota Binjai, sehingga dengan adanya hambatan-hambatan tersebut peneliti dapat mengetahui upaya-upaya apa saja yang akan dilakukan dalam mengatasi hambatan tersebut.

Dasar pelaksanaan pengelolaan PBB P2 di Kota Binjai adalah Peraturan Daerah Kota Binjai Nomor 3 Tahun 2011 tentang Pajak Daerah, sebagaimana telah diubah dengan Peraturan Daerah Kota B injai Nomor 13 Tahun 2011 tentang Pajak Daerah. Pada tahun 2017 Pemerintah Kota Binjai mengeluarkan Peraturan Walikota Binjai Nomor 47 Tahun 2017 tentang Sistem dan Prosedur Pemungutan Pajak Bumi dan Bangunan Perdesaan dan Perkotaan. Peraturan Walikota ini merupakan salah satu usaha dalam meningkatkan pelayanan kepada masyarakat di zaman serba digital untuk terwujudnya tertib administrasi pemungutan Pajak Bumi dan Bangunan Perdesaan dan Perkotaan (PBB-P2). Selain itu juga tujuan dari dikeluarkannya peraturan ini adalah usaha penyempurnakan sistem dan prosedur pemungutan pajak bumi dan bangunan perdesaan dan perkotaan untuk mewujudkan kepastian hukum terhadap hak dan 
kewajiban wajib pajak, penegakan hukum, dan meningkatkan kepatuhan wajib pajak dalam membayar PBB-P2 di Kota Binjai.

Dalam Peraturan Walikota Binjai Nomor 47 Tahun 2017 tentang Sistem dan Prosedur Pemungutan Pajak Bumi dan Bangunan Perdesaan dan Perkotaan di Kota Binjai, diatur mengenai: Pendaftaran Objek PBB P2; Pendataan Objek PBB P2; Penilaian Objek PBB P2;Mutasi PBB P2; Penetapan dan Penerbitan SPPT PBB P2; Pembayaran PBB P2; Penagihan; Keberatan; Pengurangan; Banding; Pembetulan; Pembatalan atau Pengaturan Ketetapan dan Pengurangan atau Penghapusan Sanksi Administratif; Pengembalian Kelebihan Pembayaran; Pelaporan; Pemeriksaan; Penghapusan Piutang yang sudah Kedaluwarsa; dan Insentif Pemungutan. (Peraturan Walikota Binjai Nomor 47 Tahun 2017)

Program kegiatan di atas merupakan berbagai usaha yang telah dilaksanakan Pemerintah Kota Binjai dalam upaya meningkatkan percepatan proses pembangunan. Berbagai upayapeningkatan pendapatan yang berasal dari penerimaan pajak bumi dan bangunan pada setiap tahunnya sehingga akan mempengaruhi peningkatan pendapatan daerah itu sendiri. Dengan meningkatnya pendapatan daerah tersebut, kegiatan pemerintah dalam pembangunan akan semakin meningkatkan pula sehingga usaha dalam penciptaan kesejahtraan masyarakat terus ditingkatkan.

Berikut dapat dilihat besaran angaran dan realisasi penerimaan PBB P2 di Kota Binjai dalam kurun waktu 10 tahun terakhir:

Target dan Realisasi PBB P2 Kota Binjai Tahun 2008-2018

\begin{tabular}{|c|c|c|c|}
\hline Tahun & Target & Realisasi & $\%$ \\
\hline 2008 & 4.300.000.000,- & $4.356 .711 .316,-$ & 101,32 \\
\hline 2009 & 4.909.111.00o,- & $4.544 .928 .932,-$ & 92,58 \\
\hline 2010 & 4.922.329.159,- & 4.975.491.098,- & 101,09 \\
\hline 2011 & 4.741.897.237,- & $5.289 .968 .643,-$ & 111,56 \\
\hline 2012 & $4.224 .279 .365,-$ & $5.647 \cdot 492.488,-$ & 133,69 \\
\hline 2013 & 4.660.000.000,- & $5.127 \cdot 919.647,-$ & 110,04 \\
\hline 2014 & 5.600.000.000,- & $5 \cdot 546.614 .442,-$ & 99,05 \\
\hline 2015 & 6.200.000.000,- & $5.369 .063 .223,-$ & 86,60 \\
\hline 2016 & 7.100.000.000,- & 7.312.390.000,- & 102,99 \\
\hline 2017 & 11.375.000.000,- & 8.802.139.503,- & 77,38 \\
\hline 2018 & 12.512.500.000,- & 7.706.160.505,- & 61,59 \\
\hline
\end{tabular}

Sumber: Laporan Keuangan Pemerintah Daerah (LKPD) Kota Binjai 2008-2018

Berdasarkan tabel target dan realisasi penerimaan PBB P2 Kota Binjai tahun 20082018 dapat dilihat penurunan target penerimaan PBB P2 dari tahun 2011 hingga 2013 dan mengalami kenaikan signifikan di tahun 2017 dan 2018, sedangkan pencapaian realisasi penerimaan PBB P2 dari tahun 2008 hingga tahun 2018 mengalami fluktuasi. Tahun 2013, 2015 dan 2018 terjadi penurunan realisasi penerimaan PBB P2 yang relatif signifikan jika dibandingkan dengan tahun sebelumnya.

\section{Faktor-Faktor Yang Mempengaruhi Implementasi Peraturan Walikota Tentang Intensifikasi Pengelolaan PBB-P2 Di Kota Binjai}

Komunikasi merupakan salah satu faktor yang sangat penting dan berpengaruh dalam terciptanya suatu efiensi kerja. Terwujudnya suatu komunikasi yang baik antara pemerintah dengan masyarakat akan mewujudkan adanya hubungan yang sinergis dan 
terhindar dari kesalahpahaman atau miss komunikasi sehingga tujuan yang telah dirumuskan dapat tercapai. Komunikasi dikonsepsikan sebagai proses penyampaian pesan dari seseorang kepada orang lain atau pemberian pesan dari sumber kepada penerima. Komunikasi dilihat sebagai proses linear yang menggambarkan adanya proses pemindahan sesuatu yang kongkret dari suatu tempat ketempat lain. Pesan-pesan dalam berkomunikasi dianggap sebagai suatu yang konkrit dan relatif bersifat tetap, sehingga ketika dipindahkan akan tetap dengan jumlah yang sama dan relatif bersifat tetap.

Komunikasi dalam implementasi Peraturan Walikota Binjai Nomor 47 Tahun 2017 tentang Sistem dan Prosedur Pemungutan Pajak Bumi dan Perdesaan Perkotaan di Kota Binjai kepada masyarakat diwujudkan dalam suatu penyampaian berupa informasi mengenai apa itu Sistem dan Prosedur Pemungutan Pajak Bumi dan Perdesaan Perkotaan beserta isi, serta bagaimana tata cara, prosedur dan ketentuan-ketentuan mengenai Sistem dan Prosedur Pemungutan Pajak Bumi dan Perdesaan Perkotaan yang disampaikan baik secara langsung maupun tidak langsung (Pasi, Kadir et .all, 2016).

Hal ini berdampak pada kurang maksimalnya proses penyampaian informasi yang diberikan oleh Pemerintah Kota Binjai mengenai Peraturan Walikota ini kepada masyarakat yang berakibat pada kurangnya peran serta masyarakat dalam implementasi Peraturan Walikota ini (Gosawa \& Ritonga, 2015).

Penyampaian informasi yang tidak disampaikan secara langsung oleh BPKPAD Kota Binjai secara langsung dengan sosialisasi dengan seluruh Kepala SKPD, Camat, Lurah, Kepala Lingkungan, Notaris PPAT, Tokoh Masyarakat, pelaku Usaha, dan perwakilan wajib pajak tentunya hanya sebagian masyarakat yang mengerti dan mengetahui kebijakan ini.

Selain itu Pemerintah Kota Binjai juga telah melakukanpenyesuaian Nilai Jual Objek Pajak (NJOP) Pajak Bumi dan Bangunan (PBB) Kota Binjai 2018.Penyesuaian ini dilakukan, karena NJOP (Nilai Jual Objek Pajak) di Kota Binjai belum pernah disesuaikan sejak tahun 2011, sedang kondisi pasar tanah dan bangunan terus berubah setiap tahun, sehingga nilainya sudah tidak sesuai dengan perkembangan harga pasar saat ini.

Sesuai Peraturan Daerah Kota Binjai Nomor 3 tahun 2011, besarnya NJOP ditetapkan setiap 3 tahun, kecuali untuk objek pajak tertentu dapat ditetapkan setiap tahun sesuai perkembangan wilayah. Pada tahun 2017 realisasi penerimaan PBB-P2 Kota Binjai sebesar Rp. 8,8 miliar, jumlah ini meningkat dibanding realisasi 2016 sebesar Rp. 7,3 miliar. Dengan beroperasinya jalan tol Medan-Binjai, reaktivasi kereta api BinjaiBesitang, dan kawasan industri, Binjai memiliki potensi pendapatan pajak yang cukup besar.

Berdasarkan data dan fakta yang dikumpulkan peneliti di lapangan terhadap proses komunikasi dalam pelaksanaan kebijakan Peraturan Walikota Binjai Nomor 47 Tahun 2017 tentang Sistem dan Prosedur Pemungutan Pajak Bumi dan Perdesaan Perkotaan di Kota Binjai dilakukan dengan berbagai cara antara lain yaitu:

1. Mengundang para Camat, Lurah, Kepala Lingkungan, Tokoh Masyarakat, para Notaris PPAT, perwakilan wajib pajak, pelaku usaha, dan calon wajib pajak baru dalam acara sosialisasi, seperti acara launching aplikasi E Pajak Daerah Kota Binjai. 
2. Mengeluarkan surat himbauan Walikota pembayaran PBB P2 kepada seluruh SKPD di lingkungan Pemerintah Kota Binjai.

3. Mengeluarkan surat Sekretaris Daerah mengenai himbauan PBB P2 kepala seluruh Kecamatan dan Kelurahan di lingkungan Pemerintah Kota Binjai.

4. Melakukan penyesuaian Nilai Jual Objek Pajak (NJOP) Pajak Bumi dan Bangunan (PBB) Kota Binjai 2018 dengan menghasilkan Peraturan walikota Binjai Nomor 13 Tahun 2018 tentang Klasifikasi dan Besarnya Nilai Jual Objek Pajak Sebagai Dasar Pengenaan PBB P2.

Kurangnya komunikasi kepada masyarakat secara luas dari pemerintah Kota Binjai mengenai adanya peraturan baru tentang Sistem dan prosedur Pemungutan PBB P2 kepada masyarakat menyebabkan masih adanya masyarakat yang tidak mengetahui secara jelas bagaimana Sistem dan prosedur Pemungutan PBB P2, mengingat sosialisasi mengenai peraturan ini tidak pernah dilakukan secara langsung.

Berdasarkan penjelasan di atas bahwa komunikasi yang disampaikan atau diberikan oleh Pemerintah Kota Binjai dalam hal ini BPKPAD Kota Binjai selaku lembaga teknis pengelola PBB P2 kepada masyarakat sudah dilaksanakan, namun belum merata diketahui oleh seluruh lapisan masyarakat di Kota Binjai, terbukti dengan banyaknya masyarakat yang belum mengatahui apa itu kebijakan Peraturan Walikota maupun kegiatan penyesuaian Nilai Jual Objek Pajak (NJOP) Pajak Bumi dan Bangunan (PBB) yang telah dilaksanakan pada tahun 2018 (hasil wawancara dengan kasubbid Pengendalian PBB dan BPHTB selaku informan).

\section{Sumber Daya Dalam Rangka Peningkatan Penerimaan PBB P2 di Kota Binjai}

Badan Pengelolaan KeuanganPendapatan dan Aset Daerah Kota Binjai sebagai salah satu perangkat daerah di lingkungan Pemerintah Kota Binjai yang memiliki tugas fungsi untuk melaksanakan urusan Pengelolaan Keuangan, Pendapatan dan Aset Daerah berdasarkan Peraturan Daerah Kota Binjai Nomor 4 Tahun 2016 tentang Pembentukan Perangkat Daerah Kota Binjai dan Peraturan Walikota Binjai Nomor 48 Tahun 2016 tentang Tugas Pokok dan Fungsi Badan Pengelolaan Keuangan, Pendapatan dan Aset Daerah Kota Binjai mempunyai tugas pokok "Melaksanakan penyelenggaraan Pemerintahan daerah Kota Binjai dalam pengelolaan keuangan daerah, pendapatan dan aset daerah".

Pengembangan sumber daya Peraturan Walikota Binjai Nomor 47 Tahun 2017 tentang Sistem dan Prosedur Pemungutan Pajak Bumi dan Perdesaan Perkotaan di Kota Binjai diarahkan kepada upaya peningkatan Pendapatan Asli Daerah (PAD) Kota Binjai.

Sumber Daya Aparatur, Dilihat dari segi kuantitas aparatur di Bidang PBB dan BPHTB pada BPKPAD Kota Binjai selalu bidang teknis pengelolaan PBB P2 di Kota Binjai, dirasakan cukup dalam melaksanakan implementasi Peraturan Walikota Binjai Nomor 47 Tahun 2017 tentang Sistem dan Prosedur Pemungutan PBB P2 di Kota Binjai. Bidang PBB dan BPHTB pada BPKPAD Kota Binjai di support 50 orang tenaga harian lepas yang terdiri dari: 1 orang operator IT, 6 orang petugas di loket pelayanan, 37 petugas lapangan, 6 orang petugas administrasi. Serta 15 orang staf aparatur sipil negara, 3 orang Kasubbid dan 1 orang Kepala Bidang. Melihat jumlah aparatur tersebut dengan bidang 
tugas yang ada dirasa sudah melebihi kapasitas yang dibutuhkan. Hal ini tidak terlepas dari adanya peran tekhnologi berbasis web yang telah menggantikan peran manusia secara lebih efektif dan efisien.

Berdasarkan uraian di atas diketahui bahwa ketersediaan aparatur pengelola PBB P2 di Kota Binjai sudah mengalami kelebihan sumber daya aparatur dan sebaiknya dilakukan analisis berdasarkan beban kerja dengan sumber daya aparatur yang dimiliki, pemanfaatan teknologi berbasis internet sudah tidak dapat dihindari lagi, selain efektifitas dan efisiensi anggaran, diharapkan dapat memberikan pelayanan perpajakan yang prima kepada Wajib Pajak, mendorong efisiensi waktu, tenaga, dan biaya, dapat merubah image WP yang negatif kepada aparatur pengelola pajak daerah, dan dengan penerapan E Pajak Daerah akan berdampak pada meningkatnya PAD, meminimalisir kebocoran dan kecurangan dalam pengelolaan $\mathrm{PAD}$, serta data PAD secara realtime dapat dipantau.

Sumber Daya Modal, Pemerintah Kota (Pemko) Binjai terus berinovasi untuk mewujudkan Binjai smart city dengan memberikan pelayanan yang lebih mudah dan transparan kepada masyarakat. Bekerjasama dengan Bank Sumut, Pemko meluncurkan aplikasi e-PBBdengan adanya e-PBB wajib pajak bisa melihat tagihan dan status pembayaran pajak bumi dan bangunan sektor pedesaan dan perkotaan (PBB-P2) secara langsung dan online melalui smart phone.Aplikasi ini untuk memberi kemudahan bagi para wajib pajak untuk mendapatkan informasi seputar PBB, misalnya tentang jumlah PBB yang harus dibayarkan dan tanggal jatuh tempo.

Aplikasi ePBB dapat diakses melaluisitus epbb.binjaikota.qo.id dan nantinya akan bisa didownload di playstore. Namun aplikasi ini hanya memuat informasi tentang PBB, sedang untuk pembayaran pajak harus dilakukan langsung di Bank Sumut. Walikota HM Idaham berjanji inovasi akan terus dilakukan agar masyarakat mendapatkan kemudahan untuk cara pembayaran.

Berdasarkan hasil observasi yang telah dilakukan, peneliti menilai pemanfaatan sumber daya modal yang telah dikembangkan antar pihak terkait dalam menegakkan dan mengimplementasikan Peraturan Walikota Binjai Nomor 47 Tahun 2017 tentang Sistem dan Prosedur Pemungutan Pajak Bumi dan Perdesaan Perkotaan di Kota Binjai sudah berjalan dengan baik. Hal ini dapat dilihat dari kerjasama yang baik antara BPKPAD dengan para stakeholder, yang pada akhirnya akan memberikan kemudahan akses wajib pajak dalam memenuhi kewajibannya dan akhirnya akan mempengaruhi perolehan pencapaian realisasi atas target penerimaan daerah dari sektor PBB P2 di Kota Binjai.

\section{Kendala Yang Dihadapi Dalam Usaha Peningkatan Penerimaan PBB P2 di Kota Binjai}

Berbagai permasalahan yang dihadapi dalam pelaksanaan pemungutan pajak bumi dan bangunan terdapat hampir di dalam setiap prosesnya dengan bentuk permasalahan yang berbeda-beda. Oleh karena itu permasalahan dan solusi dalam pemungutan pajak bumi dan bangunan dalam penelitian ini dikelampokkan menjadi empat bagian yaitu dalam pendaftaran dan pendataan, penghitungan, penagihan, dan pembayaran. 
Pendaftaran dan Pendataan, Tingkat kesadaran wajib pajak di Kota Binjai termasuk dalam katagori rendah. Hal ini dapat dilihat dari jumlah Surat Pemberitahuan Pajak Terutang (SPPT) setiap tahunnya rata-rata memiliki peningkatan di bawah $10 \%$. Surat Pemberitahuan Pajak Terutang (SPPT) adalah Surat Keputusan Kepala KPP mengenai pajak terutang yang harus dibayar dalam 1 (satu) tahun pajak. Mendapatkan penjelasan berkaitan dengan ketetapan PBB dalam hal Wajib Pajak meminta dan SPPTPBB digunakan untuk menentukan objek pajak yang dibebankan pajak yang harus dibayarkan kepada negara oleh orang yang namanya tercantum dalam dokumen. Hal ini dapat dilihat pada tabel di bawah ini;

Jumlah SPPT (Surat Pemberitahuan Pajak Terutang) PBB P2 Se Kota Binjai TA 2008-2018

\begin{tabular}{lll}
\hline No & Tahun & Jumlah \\
\hline 1. & 2008 & 62.778 \\
2. & 2009 & 63,866 \\
3. & 2010 & 65,530 \\
4. & 2011 & 66,911 \\
5. & 2012 & 68,435 \\
6. & 2013 & 69,091 \\
7. & 2014 & 69,798 \\
8. & 2015 & 70,765 \\
9. & 2016 & 71,554 \\
10. & 2017 & 72,728 \\
11. & 2018 & 74,104 \\
\hline
\end{tabular}

Sumber: Bidang PBB BPHTB, BPKPAD Kota Binjai, 2019.

Hal ini dapat dilihat dari proses pembayaran kewajiban, dimana para petugas di lapangan masih harus secara door to door melakukan pemungutan kerumah warga untuk melaksanakan kewajibannya. Wajib pajak cenderung acuh tak acuh dan mengabaikan anjuran membayar pajak dengan alasan yang beragam. Pembayaran tagihan PBB P2 umumnya dilakukan apabila wajib pajak tersebut akan melakukan proses jual beli atau proses administrasi kependudukan dimana pihak kelurahan menerapkan kebijakan mewajibkan untuk menyelesaikan seluruh tunggakan PBB P2 apabila akan ingin mengurus administrasi kependudukan di Kantor Kelurahan. Hal seperti inilah yang memicu tidak tercapainya target penerimaan pajak yang telah ditetapkan. Rata-rata realisasi penerimaan masih berada di bawah targetnya.

Beberapa permasalahan yang umumnya terjadi dalam penatausahaan PBB P2 di Kota Binjai antara lain:

1. Harga nilai jual obyek pajak (NJOP) umumnya tidak sesuai dengan harga pasar yang berlaku saat itu. Antara harga NJOP dengan harga pasar seringkali berbeda. Hal ini disebabkan karena harga tanah yang semakin lama semakin naik dan diminati banyak orang. Contohnya harga tanah di jalan Jend. Sudirman yang merupakan jalan utama, rata-rata dikenakan NJOP sekira $\quad$ Rp. 1.500 .000 per meter persegi, padahal harga tanah di sekitar lokasi tersebut dapat mencapai Rp. 5.000.000 sampai dengan Rp. 8.000.000 per meter persegi.

2. Pengajuan pemecahan obyek pajak. Misalnya wajib pajak mengajukan pemecahan karena warisan. Satu obyek pajak dipecah menjadi dua. Pada tahun regular atau 
tahun pemecahan hal tersebut bisa terlaksana tetapi untuk tahun-tahun berikutnya induk obyek yang dipecah muncul lagi sehingga wajib pajak menerima dua SPPT.

3. Masih terdapat beberapa data wajib pajak yang diterbitkan KPP belum valid Beberapa data wajib pajak yang diterbitkan KPP ada yang belum valid karena banyak obyek pajak yang sudah pindah tangan atau berganti kepemilikan tanpa melapor, terkadang terdapat juga ukuranobyek yang berbeda dan alamat wajib pajak tidak diketahui/ pindah alamat.

Berdasarkan realisasi penerimaan PBB P2 per Kecamatan, dapat dilihat dalam tabel berikut:

Laporan Realisasi Penerimaan PBB P2 Per Kecamatan Se Kota Binjai TA 2017-2018

\begin{tabular}{llll}
\hline No & Kecamatan & 2017 & 2018 \\
\hline 1. & Kecamatan Binjai Kota & 1.627 .172 .208 & 1.572 .435 .739 \\
2. & Kecamatan Binjai Utara & $\mathbf{2 . 0 2 8 . 1 6 5 . 8 0 0}$ & 1.770 .398 .106 \\
3. & Kecamatan Binjai Selatan & 1.147 .126 .623 & 1.056 .656 .008 \\
4. & Kecamatan Binjai Timur & 1.927 .428 .458 & 1.509 .908 .149 \\
5. & Kecamatan Binjai Barat & $\mathbf{2 . 0 7 2 . 2 4 6 . 4 1 4}$ & 1.796 .762 .503 \\
\hline
\end{tabular}

Sumber: BPKPAD Kota Binjai, 2019.

Berdasarkan tabel 4.3 tentang Laporan Realisasi Penerimaan PBB P2 Per Kecamatan Se Kota Binjai TA 2017-2018 di atas dapat dilihat realisasi penerimaan PBB P2 pada tahun 2018 diseluruh kecamatan mengalami penurunan jika dibandingkan dengan tahun sebelumnya.

Berdasarkan penuturan informan, dapat disimpulkan bahwa penurunan realisasi penerimaan PBB P2 diseluruh Kecamatan di Kota Binjai merupakan efek dari adanya pembayaran hutang PBB berikut dendanya pada tahun 2017 sehingga ditahun 2018 pajak terhutang berikut dendanya sudah tidak banyak lagi, selain itu tahun 2018 program operasi sisir hanya dilaksanakan 2 bulan sedangkan tahun 2017 program operasi sisir dilaksanakan selama 6 bulan.

Dalam prakteknya di lapangan, sering dijumpai adanya tindakan perlawanan/penghindaran pajak (TaxAvoidance) pengumutan pajak. Salah satu bentuk tindakan perlawanan/penghindaran pajak adalah kasus penghindaraan pajak bumi dan bangunan pedesaan dan perkotaan (PBB P2) yang umumnya dilakukan karena ketidakseimbangan antara kepemilikan tanah dan bangunan yang dimiliki wajib pajak, yang merupakan hasil dari warisan dan kemampuan ekonomi wajib untuk melaksanakan kewajiban perpajakan tersebut.

\section{Dalam Penagihan}

Wajib pajak menghindar saat ditagih, Di beberapa kasus, terkadang wajib pajak belum mempunyai uang untuk membayar pajaknya pada hari yang telah ditetapkan. Untuk menghindari petugas penagih mereka seringkali beralasan tidak berada ditempat atau sedang sibuk dan tidak bisa diganggu. Namun ada juga wajib pajak yang benarbenar tidak berada ditempat pada waktu pembayaran sehingga petugas tidak dapat menagih saat itu juga dan harus ditunda sampai wajib pajak yang bersangkutan kembali.

Adanya kumulatif pembayaran tunggakan, Jika wajib pajak mempunyai tunggakan dalam waktu yang cukup lama dan jumlahnya cenderung besar mereka biasanya tidak melunasi tunggakan pajaknya sekaligus. Misalnya wajib pajak A mempunyai tunggakan 
selama 10 tahun terdiri dari tunggakan pokok dan denda yang relatif besar dan jumlah tunggakannya mencapai jutaan rupah biasanya mereka membayar untuk 2 atau 3 tahun dulu dan membayar setengah dari jumlah keseluruhan tunggakan dengan alasan dana yang tersedia saat itu hanya cukup untuk membayar setengahnya saja. Tentunya hal seperti ini akan berpengaruh pada penerimaan pajak tahun yang bersangkutan.

\section{Upaya-Upaya yang dilakukan untuk Mengatasi Kendala dalam Pengelolaan PBB P2 di Kota Binjai}

Dalam rangka optimalisasi pemungutan Pajak Bumi dan Bangunan (PBB) P2 yang perlu diperhatikan selanjutnyaadalah pelaksanaan sistem dan prosedurpemungutan, petugas pemungutan dansarana dan prasarana serta pengawasan yangdilakukan, karena bagaimana pun tingginyakesadaran masyarakat namun jikapemungutannya tidak dilaksanakan denganbaik maka upaya tersebut tetap tidak akanmampu mewujudkan suatu tingkatpenerimaan pajak seperti yang diharapkan. Berbagai upaya yang dilakukan Pemerintah Kota Binjai melalui Bidang PBB dan BPHTB pada Badan Pengelolaan Keuangan Pendapatan dan Aset Daerah (BPKPAD) Kota Binjai dalam mengatasi berbagai kendala yang dihadapi.

Berdasarkan penuturan informan, secara fakta di lapangan dapat dilihat upaya yang telah dilakukan dalam rangka pengelolaan dan peningkatan penerimaan PBB P2 di Kota Binjai telah dijalankan proses komunikasi dan koordinasi dengan stakeholder terkait merupakan salah satu langkah preventif dalam upaya peningkatan penerimaan PAD dari sektor PBB P2. Selain itu Bidang PBB dan BPHTB juga melakukan program pemutihan denda PBB P2 bagi wajib pajak yang membayar tunggakan dalam jangka waktu bulan Oktober hingga Desember 2018, selain itu juga guna memudahkan wajib pajak dalam membayar tunggakan, disediakan loket pembayaran bank Sumut di loket pelayanan administrasi PBB P2 pada Kantor BPKPAD Kota Binjai sehingga wajib pajak tidak perlu mengantre di tellerBank, melakukan kegiatan pemutakhiran Zona Nilai Tanah (ZNT) PBB P2 di Kota Binjai, melakukan operasi sisir secara rutin guna menggali potensipotensi PBB P2 yang belum terdata, pemanfaatan sumber daya aparatur dan sumber daya modal berupa aplikasi berbasis web, media massa dan elektronik yang semuanya bertujuan untuk semakin memudahkan wajib pajak dalam melaksanakan kewajiban perpajakannya. Secara khusus BPKPAD Kota Binjai tidak melakukan sosialisasi langsung kepada masyarakat seluruhnya, sosialisasi yang dilakukan hanya dengan melibatkan struktur birokrasi terkait.

\section{SIMPULAN}

Faktor-faktor yang mempengaruhi implementasi Peraturan Walikota tentang intensifikasi pengelolaan PBB-P2 di Kota Binjai yaitu faktor komunikasi dan pemanfaatan sumberdaya. Kendala-kendala yang dihadapi dalam menjalankan usahausaha intensifikasi dalam meningkatkan penerimaan PBB-P2 antara lain yaitu; minimnya sosialisasi kepada masyarakat secara langsung, penentuan target penerimaan terlalu tinggi akibat proses penentuan potensi target penerimaan PBB P2 tidak melalui penghitungan secara studi akademis melainkan hanya memperkirakan dari ketetapan jumlah PBB se Kota Binjai ditambah besaran piutang. 
Upaya-upaya yang telah dilakukan dalam mengatasi kendala yang dihadapi dalam pengelolaan PBB P2 antara lain dengan mengintensifkan komunikasi dan koordinasi dengan seluruh stakeholder terkait pengelolaan PBB P2 di Kota Binjai; melakukan upaya preventif dalam pendekatan kepada masyarakat dan wajib pajak untuk meningkatkan kesadaran taat pajak; meningkatkan kompetensi para aparatur pengelola PBB P2; melakukan program pemutihan denda PBB P2; penyediaan loket pembayaran bank Sumut di loket pelayanan administrasi di Kantor BPKPAD Kota Binjai, melakukan kegiatan pemutakhiran Zona Nilai Tanah (ZNT), melakukan operasi sisir secara rutin, pemanfaatan aplikasi berbasis web, media massa dan elektronik.

\section{DAFTAR PUSTAKA}

Erlina. (2011). Metodologi Penelitian. USU Press. Medan.

Gaffar, A. (2009). Politik Indonesia: Transisi Menuju Demokrasi. Yogyakarta: Pustaka Pelajar.

Halim, A. (2004). Bunga Rampai Manajemen Keuangan Daerah. Yogyakarta. UPP AMP YKP.

Hendrawan, A.I. Kusmanto, H. \& Warjio. (2018). Pengaruh Kualitas Pelayanan terhadap Kepuasan Publik di Badan Pengelolaan Pajak dan Retribusi Daerah Kota Medan. Jurnal Administrasi Publik : Public Administration Journal. 8 (1): 65-84.

Henry, K., Harmer, J., Piggott, J., Ridout, H., Smith, G., (2009). Australia'S Future Tax System. Canberra Commonw. Treas.

Isnanto, A. (2014). Standar Pengajuan Pajak Bumi dan Bangunan. Bahari Press. Yogyakarta.

Kadir, A. (2018). Analisis Penetapan Nilai Jual Obyek Pajak Bumi dan Bangunan Sektor Perkebunan sebagai Upaya Peningkatan Sumber Pendapatan Daerah. Journal of Education, Humaniora and Social Sciences (JEHSS). 1 (1): 9-15.

Kamus Besar Bahasa Indonesia. (2015). Tim Prima Pena. Gita Media Press.

Kuncoro, M. (2009). Metode Riset Untuk Bisnis \& Ekonomi. Penerbit Erlangga. Jakarta.

Laporan Kuangan Pemerintah Daerah (LKPD) Kota Binjai 2014-2017 Audited.

Mardiasmo. (2009). Akuntansi Sektor Publik. Yogyakarta. ANDI.

Mardiasmo. (2011). Perpajakan Edisi Revisi. Yogyakarta. ANDI.

Masyhuri dan M. Zainuddin. (2008). Metodologi Penelitian Sosial dan Ekonomi, Teori dan Aplikasi. Bandung. Penerbit Alfabeta.

Mirrlees, J., Adam, S., (2011). Tax by Design: The Mirrlees Review. Oxford University Press

Raharjo, Adisasmita. (2010). Pembangunan dan Tata Ruang. Yogyakarta: Graha Ilmu.

Resmi, S. (2012). Perpajakan teori dan Kasus. Jakarta. Salemba Empat.

Sanusi, A. (2012). Metodologi Penelitian Bisnis. Jakarta. Salemba Empat.

Sedarmayanti. (2014). Sumber Daya Manusia dan Produktivitas Kerja. Jakarta: Mandar Maju.

Siagian, S.P, (2008). Manejemen Sumber Daya Manusia. Cetakan Enam Belas. Jakarta: Bumi Aksara.

Siahaan, P.M. (2010). Pajak Daerah dan Retribusi Daerah. Jakarta. PT Raja Grafindo Persada.

Sinulingga, L.O. Nasution, M.H.T. \& Batubara, B.M. (2018). Implementasi Kebijakan Pajak Progresif Bagi Kendaraan Bermotor. PERSPEKTIF, 7 (1): 19-23

Sugiyono. (2014). Metode Penelitian Bisnis. Bandung. Penerbit Alfabeta.

Suparmo \& Theresia. (2010). Perpajakan Indonesia.Jakarta. Andi.

Sutedi, A. (2008). Hukum Pajak dan Retribusi Daerah. Bogor. Ghalia.

Wahab, S,A. (2008). Analisis Kebijakan I. Jakarta. Haji Mas Agung.

Waluyo. (2011). Perpajakan Indonesia. Jakarta. Salemba Empat.

Widodo, J. (2010). Analisis Kebijakan Publik, Konsep dan Aplikasi Analisis Kebijakan Publik. Malang: Bayu Media.

Winarno, B. (2008). Kebijakan Publik: Teori dan Proses Edisi Revisi. Yogyakarta. Media Presindo.

Ngarsiningtyas, S.K. \& Sembiring, W.M. (2016) Peran Badan Permusyawaratan Desa dalam Penyusunan dan Penetapan Peraturan Desa, JPPUMA: Jurnal Ilmu Pemerintahan dan Sosial Politik UMA (Journal of Governance and Political UMA), 4 (2): 159-172.

Pinayungan, J., Kusmanto, H. \& Isnaini. (2018). Implementasi Peraturan Menteri Perhubungan Republik Indonesia Tentang Standar Keselamatan Lalu Lintas Dan Angkutan Jalan. Jurnal Administrasi Publik: Public Administration Journal: Public Admnistration Journal. 8 (1): 108-123 
Pasi, N., Abdul K. \& Isnaini, (2016), Implementasi Sistem Informasi Manajemen Daerah Keuangan Berbasis Akrual pada Pemerintah Kebupaten Dairi, Jurnal Administrasi Publik : Public Administration Journal : Public Admnistration Journal, 7 (1): 49-63

Gowasa, I., \& Ritonga, S. (2015). Implementasi Program Raskin Untuk Membantu Perekonomian Masyarakat Miskin Di Kecamatan Tanah Masa Kabupaten Nias Selatan, Jurnal Administrasi Publik Universitas Medan Area, 3 (2): 97-111 